\title{
The relationship between the quality of school life and the school burnout
}

\author{
Selim Gündoğan ${ }^{1}$, Hatice Özgen ${ }^{2}$ \\ ${ }^{1}$ Department of Educational Sciences, Niğde Ömer Halisdemir University, Turkey \\ ${ }^{2}$ Ministry of National Education, Republic of Turkey, Turkey
}

\section{Article Info \\ Article history: \\ Received Apr 22, 2020 \\ Revised Jun 27, 2020 \\ Accepted Jul 23, 2020}

\section{Keywords:}

Quality of school life

School burnout

Secondary school student

Structural equation model

\begin{abstract}
School burnout has been a research subject during recent years and is a wide case among students is associated with many factors. Among these factors, school-related concepts are remarkable. Within this study, it is aimed to investigate the relationship between school quality, school burnout and school burnout. The participant group of the study consists of a total of 364 secondary school students, 181 girls and 183 boys, whose ages are in the range of 10-15, attending various secondary schools. This sampling was determined by the maximum diversity sampling method. The data were collected with the school quality of life and school burnout scale. In the analysis of the data, correlation and structural equation model analysis were administrated. It was concluded that there is a negative relationship between school quality of life and school burnout, and that school quality of life is a negative predictor of school burnout. The results were discussed through the literature review and suggestions were made for researchers and practitioners.
\end{abstract}

This is an open access article under the CC BY-SA license.

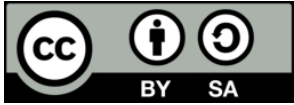

\section{Corresponding Author:}

Selim Gündoğan,

Department of Educational Sciences,

Faculty of Education,

Niğde Ömer Halisdemir University,

Niğde, Turkey.

Email: selimgundogan1453@hotmail.com

\section{INTRODUCTION}

Schooling is a process creating greater demands on students. Accordingly, the schooling process may cause students to experience fatigue against school, lessons, and homework [1]. This is the reason why the concept of "school burnout" has been a research subject through the science world [2-4] School burnout can affect students not only academically but also psychologically, socially and even physically [2, 3, 5]. The fact that going to school regularly of students, just like an employee, and facing the duties, responsibilities and demands required by school life, has resulted in the association of these forms of reaction attributed to the concept of burnout with student life [1, 3, 6-11].

School burnout is defined as the students experiencing a sense of burnout and exhaustion as well as developing a careless and cynical attitude towards the school as a result of the responsibilities and expectations that the school display on students [1, 12]. According to Aypay [8], school burnout is defined as "Burnout syndrome of students caused by excessive demands of school and education". Intense expectations of the school or student itself, homework, parents' expectations of success from students, stressful situations in the education life, the difficulty of the content of the courses are the factors that increase school burnout $[13,14]$. School burnout, common among students, has been found to be associated 
with many concepts $[5,15,16]$. Studies show that school burnout experienced by students caused many negative situations such as low academic performance [17, 18], school absenteeism and school dropout [19, 20], and mental problems (depression, anxiety, stress) [21-23].

It has been suggested that factors that prevent and reduce negativity caused by school burnout are factors that result from the individual [3, 24, 25], school [8] and social environment [4, 26, 27]. It was observed that the concepts like school engagement [28-31], and school climate [32, 33] were negatively related to school burnout and were factors to decrease school burnout. One of the factors associated with the school in question, which has a positive effect on the negative situations seen in students, can be considered to be the "quality of school life" [34, 35].

The concept of quality of school life was first conceptualized by Epstein and Mcpartland [36, 37] based on the concept of quality of life. Quality of School life is defined as 'a well-being based on students' perceptions and evaluations about the school that they attend" [38]. In another definition, the quality of school life is explained as "the general happiness of the student in the educational environment, satisfaction or well-being obtained from the current conditions" [39]. School quality of life is considered as one of the indicators of general well-being, and it is considered also as well-being as a result of students' good connection with school life [40]. The high quality of school life has many important implications for students [41, 42]. There are several studies indicating that high perception of school life quality of students increases happiness in students [43], reflects positively on learning motivation [44], reduces absenteeism to school and lessons [45], and lowers the sense of alienation to school [46]. All these findings illustrates that high quality of school life reflects positively to students, while low results lead to negative situations in students.

Consequently, it can be said that quality of school life is a concept that has a positive reflection on many situations of students and has an important role in overcoming the negative situations seen in students. It is believed that the concept in question is negatively related to school burnout, which is widely seen in students and cause many negativities from school life to normal life and also quality of school life has a protective role. In addition, it is thought that the school life quality, which has an important role in overcoming the negativities of school burnout, is important in terms of preventive guidance services. For this purpose, it was aimed to examine the effect of school life quality on school burnout in this study in order to shed light on preventive guidance services. In addition, while there are studies through the literature examining the effects of school loyalty and school climate, which are factors related to school, on school burnout, it is noteworthy that there is no study examining the effect of school quality of life, one of the factors associated with school, on school burnout. In this context, this study is intended to shed light on other studies on this subject and to introduce a specific study to the relevant literature that examines the relationship between school quality of life and school burnout. Based on these aspects, answers to the following questions were sought in this study: (1) Is there a significant relationship between quality of school life and school burnout? (2) Is school quality of life a significant predictor of school burnout?

\section{RESEARCH METHOD}

\subsection{Research design}

This study is a "correlational survey model" examining the relationship between two quantitative variables (quality of school life-school burnout) [47]. Through this purpose, the structural equation model was used to examine the relationship between the two variables. Structural equation model is an analysis method that examines the direct and indirect relationship between observable and latent variables [48]. In this study, the predictive effect of the latent variable of school life quality, which includes 5 observable variables including teachers, students, feelings about school, school management and status on school burnout latent variable, which includes 3 observable variables: emotional burnout, depersonalization and feeling of low success were investigated.

\subsection{Participants}

Participants of the study were determined by using maximum diversity sampling method, which is one of the convenience sampling methods [47]. The maximum diversity sampling method is a sampling method that allows groups with different characteristics to be included in the study [47]. In this context, five secondary schools with different socio-cultural and economic characteristics in Niğde province were determined by using maximum diversity sampling method and data were collected from these schools' students who volunteered to participate in the study. The participants of the study consisted of a total of 364 secondary school students, 181 females and 183 males, who continue their secondary education in the province of Niğde, with the age range of 10-15. 


\subsection{Data collection tools}

Quality of school life scale (SQL): School quality of life scale was developed by Sar1. Later, Sar1 [34] tested its validity and reliability again. The reliability and validity study of the scale was administrated on 578 students attending to primary schools between 4th grade and 7th grade. As a result of the factor analysis, a measurement tool with a total of 35 items was obtained, which explained $46.92 \%$ of the total variance consisting of sub-dimensions of "teachers", "students", "feelings about school", "school management" and "status". The Cronbach Alpha internal consistency coefficients for these five dimensions were found as $.83, .80, .82, .77$ and.69 respectively. As a result of the confirmatory factor analysis, it was concluded that the scale gives compatible results $(\chi 2=2003.03, \mathrm{sd}=547, \mathrm{p}<.001, \chi 2 / \mathrm{sd}=3.66, \mathrm{RMSEA}=0.068$, $\mathrm{NNFI}=0.94, \mathrm{CFI}=0.95$ and $\mathrm{GFI}=0.83$ ) [34]. In this study, the internal consistency coefficient was found as .87 for the wholescale and $.81, .74, .78, .77, .73$ for each sub-dimension, respectively.

School burnout Inventory (SBI): The adaptation studies of the school burnout scale developed by Salmela-Aro, Kiuru, Leskinen and Nurmi [1] into Turkish were conducted by Seçer et al. [49]. The study group of the study consisted of 570 students studying in primary and secondary schools in Erzurum city center. Translation processes were then carried out with the opinion of the expert for language validity. Exploratory and confirmatory factor analysis studies were conducted for construct validity. With the results of exploratory factor analysis, a three-factor structure was obtained as "emotional burnout", "desensitization", "low personal feeling of success" as in its original form, explaining 66,858\% variances in three dimensions. Model fit of this three-dimensional structure was tested by confirmatory factor analysis and it was found that the fit indexes were at a good level. $(\mathrm{X} 2=41.97, \mathrm{sd}=21, \mathrm{p}=.00, \mathrm{X} 2 / \mathrm{sd}=1.99, \mathrm{RMSEA}=.042, \mathrm{RMR}=.013$, $\mathrm{NFI}=.98, \mathrm{NNFI}=.98, \mathrm{CFI}=.99, \mathrm{IFI}=.99, \mathrm{RFI}=.96, \mathrm{AGFI}=.93, \mathrm{GFI}=.97)$. As a result of the reliability analysis of the scale, the internal consistency coefficient was found as .75 and the test-retest reliability was .80 [49]. In this study, the internal consistency coefficient was .87 for the whole scale, .71 for the emotional burnout sub-dimension, .78 for the depersonalization sub-dimension, and .63 for the feeling of low personal accomplishment sub-dimension.

\subsection{Procedure and data analysis}

After obtaining the necessary ethical permissions for the study, five secondary schools with different socio-cultural and economic characteristics were determined in the province of Niğde and data were collected from secondary school students who volunteered to participate in the study. The data gathered from the participants who responded completely to the survey were included in the analyzing process. For the analysis of the data, normal distribution of the data were tested, skewness and kurtosis values were examined; it was concluded that the values in question ranged between -1 and +1 , and it has been determined that the data showed a normal distribution (Table 1) [50]. The mahalanobis and cook's values of the data were examined, and it was not necessary to extract any data since it was seen that there was no extreme value to be discarded (highest mah. = 17.58/highest cook's $=.056$ ) [51]. In the first phase of analysis, the correlation analysis was performed. It was observed that there were relationships less than .80 between the variables and it was concluded that there were no multiple correlation problems [52]. In the structural equation model analysis, the $<5$ value for $\chi 2$ / df was taken as a criterion [53]; for NFI, CFI, GFI, TLI and IFI values, $\geq .90$ value was taken as a criterion $[50,54,55]$; for AGFI $\geq .80$ value was taken as a criterion [56] and for RMSEA $\leq .08$ value was taken as a criterion [50]. It has been suggested that the confirmatory factor analysis of the scales and the model fit should be examined before the structural equation model analysis $[48,57]$. In this context, before the structural equation model analysis, the confirmatory factor analysis of the scales was conducted and the model fit was examined (Table 2). The predictability of quality of school life to school burnout was tested by structural equation model analysis after the conclusion that the scales have good model fit and model fit (Figure 1 and Table 3).

\section{RESULTS AND DISCUSSION}

\subsection{Results}

In the results section, summarize the collected data and the analysis performed on those data relevant to the In this section, findings regarding the correlation analysis related to the relationship between quality of school life and school burnout and findings about whether school quality of life is a significant predictor of school burnout are included. Table 1 represents that there is a negative and significant relationship between all sub-dimensions of school life quality and all sub-dimensions of school burnout as a result of the correlation analysis conducted to examine the relationship between school quality of life and school burnout $(\mathrm{p}<.01)$. Moreover, skewness and kurtosis values are between -1 and +1 for all variables, and the data show a normal distribution for all variables [50]. 
Table 1. Correlations and descriptive statistics among study variables

\begin{tabular}{|c|c|c|c|c|c|c|c|c|}
\hline & 1 & 2 & 3 & 4 & 5 & 6 & 7 & 8 \\
\hline 1. Emotional Exhaustion & 1 & & & & & & & \\
\hline 2. Depersonalization & $705^{* *}$ & 1 & & & & & & \\
\hline 3. Low sense of success & $.639^{* *}$ & $.679^{* *}$ & 1 & & & & & \\
\hline 4. Teachers & $-.366^{* *}$ & $-.464^{* *}$ & $-.410^{* *}$ & 1 & & & & \\
\hline 5. Students & $-.288^{* *}$ & $-.135^{* *}$ & $-.189^{* *}$ & $.364^{* *}$ & 1 & & & \\
\hline 6. Feelings towards school & $-.231^{* *}$ & $-.275^{* *}$ & $-.252^{* *}$ & $.564^{* *}$ & $.131^{* *}$ & 1 & & \\
\hline 7. School management & $-.180^{* *}$ & $-.232^{* *}$ & $-.151^{* *}$ & $.496^{* *}$ & $.110^{* *}$ & $.420^{* *}$ & 1 & \\
\hline 8. Status & $-.224^{* *}$ & $-.182^{* *}$ & $-.194^{* *}$ & $.273^{* *}$ & $.117^{* *}$ & $.312^{* *}$ & $.154^{* *}$ & 1 \\
\hline Mean & 9.777 & 5.881 & 4.156 & 32.645 & 23.744 & 30.794 & 17.854 & 11.431 \\
\hline Std. Deviation & 4.141 & 3.175 & 2.241 & 8.038 & 7.415 & 6.891 & 6.115 & 3.195 \\
\hline Skewness & .449 & .987 & .877 & -.331 & .181 & -.674 & -.097 & -.847 \\
\hline Kurtosis & -.681 & .023 & -.174 & -.407 & -.524 & .142 & -.838 & .047 \\
\hline
\end{tabular}

After finding a significant relationship between school quality of life and school burnout, firstly, the confirmatory factor analysis of the scales was conducted to examine whether school quality of life was a significant predictor of school burnout, and then a measurement model was established and tested (Table 2). Whether the school quality of life was a significant predictor of school burnout was tested using the structural equation model after the results fit well. The model is shown in Figure 1, and fit indices are shown in Table 3. When Table 2 is analyzed, it is seen that the model fit of quality of school life and school burnout scale and fit indexes of the established model are at desired values. The findings regarding the structural equation model established to reveal the relationships between school quality of life and school burnout are given in Figure 1. When Table 3 is examined, it is seen that the model established to determine whether quality of school life is a significant predictor of school burnout is confirmed and it is determined that quality of school life is a negative predictor of school burnout $\left(\mathrm{R}^{2}=.31, \mathrm{p}<.001\right)$. Table 4 is concerned with the results regarding standard regression weights and $\mathrm{R}^{2}$.

Table 2. Model fit indices

\begin{tabular}{|c|c|c|c|c|}
\hline \multirow{2}{*}{ Fit Indices } & \multicolumn{2}{|c|}{ Scales } & \multirow{2}{*}{$\begin{array}{c}\text { Structural } \\
\text { Model }\end{array}$} & \multirow{2}{*}{$\begin{array}{c}\text { Reference } \\
\text { Value(s) }\end{array}$} \\
\hline & *SQL & $* \mathrm{SBI}$ & & \\
\hline$\chi^{2}$ & 79.13 & 992.73 & 57.47 & \\
\hline$p$ value & $<.001$ & $<.001$ & $<.001$ & \\
\hline df & 24 & 543 & 19 & \\
\hline$\chi^{2} / \mathrm{df}$ & 3.29 & 1.82 & 3.02 & $<5[53]$ \\
\hline NFI & .93 & .91 & .95 & $\geq .90[50]$ \\
\hline AGFI & .91 & .84 & .93 & $\geq .80[56]$ \\
\hline CFI & .95 & .91 & .97 & $\geq .90[55]$ \\
\hline RMSEA & .08 & .04 & .07 & $\leq .08[50]$ \\
\hline
\end{tabular}

*(SQL= Quality of School Life Scale; SBI: School Burnout Inventory)

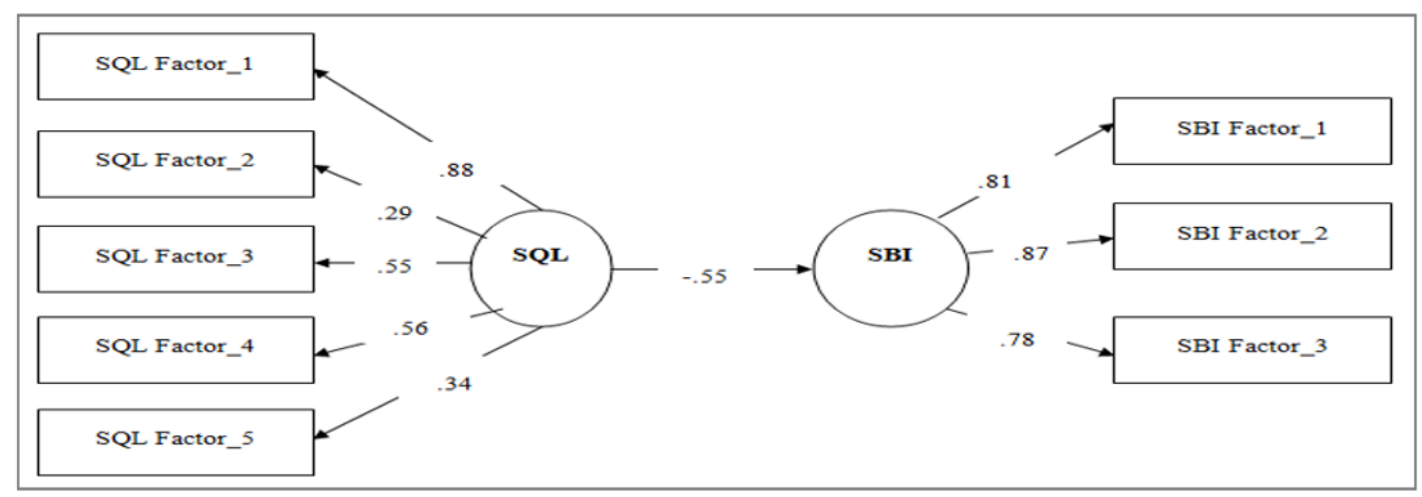

Figure 1. Structural equation model illustrating the relationship between quality of school life and school burnout 
Table 3. The fit indices values of the tested model

\begin{tabular}{ccc}
\hline Fit Indices & Structural Model & Reference Value(s) \\
\hline$\chi^{2}$ & 57.59 & \\
$p$ value & $<.001$ & \\
$\mathrm{df}$ & 19 & $<5[53]$ \\
$\chi^{2} / \mathrm{df}$ & 3.03 & $\geq .90[50]$ \\
NFI & .94 & $\geq .80[56]$ \\
AGFI & .92 & $\geq .90[55]$ \\
CFI & .95 & $\geq .90[50]$ \\
GFI & .96 & $\geq 0.90[54]$ \\
TLI & .94 & $\geq 0.90[55]$ \\
IFI & .95 & $\leq .08[50]$ \\
RMSEA & .07 &
\end{tabular}

Table 4. Predictive analysis results

\begin{tabular}{|c|c|c|c|c|c|c|c|c|}
\hline & & & $\begin{array}{c}\text { Std. Regression } \\
\text { Weights }\end{array}$ & Estimate & $\begin{array}{l}\text { Std. } \\
\text { Error }\end{array}$ & $\begin{array}{c}\text { Critical } \\
\text { Radio }\end{array}$ & $\mathrm{R}^{2}$ & $\mathrm{p}$ \\
\hline SBI & <--- & SQL & -.554 & -.261 & .031 & -8.452 & .31 & *** \\
\hline SQL_FACTOR_1 & $<---$ & SQL & .881 & 1.000 & & & .78 & \\
\hline SQL_FACTOR_2 & $<---$ & SQL & .286 & .299 & .060 & 4.993 & .08 & $* * *$ \\
\hline SQL_FACTOR_3 & $<--$ & SQL & .650 & .632 & .058 & 10.960 & .42 & $* * *$ \\
\hline SQL_FACTOR_4 & $<---$ & SQL & .559 & .483 & .050 & 9.638 & .31 & *** \\
\hline SQL_FACTOR_5 & $<---$ & SQL & .341 & .154 & .026 & 5.959 & .12 & *** \\
\hline SBI_FACTOR_1 & $<---$ & SBI & .806 & 1.000 & & & .65 & \\
\hline SBI_FACTOR_2 & $<---$ & SBI & .874 & .832 & .049 & 16.814 & .76 & *** \\
\hline SBI_FACTOR_3 & $<---$ & SBI & .784 & .526 & .034 & 15.583 & .61 & $* * *$ \\
\hline
\end{tabular}

When Table 4 is examined, quality of school life explains $31 \%$ of school burnout. This finding reveals that school quality of life has a negative effect on school burnout. In addition, the explanation rates in the two latent variables of the sub-dimensions which are observable variables of the school quality of life and school burnoutlatent variablesare also shown in the table. Teachers sub-dimension explains $78 \%$ of school life quality, students sub-dimension explains $8 \%$, school emotions sub-dimension explains $42 \%$, school management sub-dimension explains $31 \%$ and status sub-dimension explains $12 \%$. The emotional burnout sub-dimension of school burnout explains $65 \%$, the depersonalization sub-dimension explains $76 \%$, and the low personal sense of success sub-dimension explains $61 \%$.

\subsection{Discussion}

School burnout has been handled as a situation that causes many problems for students who continue their education life [28, 58]. Within this study, it was aimed to investigate whether school life quality, which is regarded to be negatively related to school burnout, is a significant predictor of school burnout. The study examined whether there is a significant relationship between school quality of life and school burnout and whether school quality of life is a significant predictor of school burnout. As a result of the correlation analysis, it was concluded that there were negative relationships between all sub-dimensions of school life quality and all sub-dimensions of school burnout. As a result of the structural equation model analysis, it was found that school life quality is a negative predictor of school burnout. In other words, school life quality negatively affects school burnout. According, it can be argued that a good level of school life quality will adversely affect the school burnout score.

Through the literature review, no study that directly examines the relationship between school burnout and school quality of life has been conducted. Studies have concluded that there is a negative relationship between work quality of life and burnout [59-62]. In addition to these, it was concluded that there is a negative relationship between school engagement and school burnout [28-31]. Also, it was concluded that there is a negative relationship between school climate and school burnout [32, 33]. These studies are in line with the results obtained in this study and support the finding of this study. The findings show that school quality of life adversely affects school burnout. In other words, as students' perceptions about school life quality increase, it can be said that school burnout decreases.

According to the results of this study, it can be argued that the applications and activities that will be carried out in order to increase the quality of school life will play an important role in the students' coping with the negativities of school burnout more effectively and in less experiencing school burnout. Indeed, it has been suggested that factors that affect school burnout are effective in reducing the frequency of school burnout [28, 33]. In this regard, considering the quality of school life is one of the factors related to the school, It can be argued that teachers and school administrators, who are the components of school life 
quality, have an important role and responsibility in improving quality of life in schools [34, 46]. Thus, it can be assumed that it will contribute to observing the negative effects of the school burnout at minimum levels, which is seen as a common situation among students.

This study has some limitations. The first limitation is that the study group consists of secondary school students only in Niğde province. This limitation can be reduced by including students from different cities and regions in the study group for future studies. In addition, the data in the study were collected with scales answered by the participants based on their self-reports. In new studies, this limitation can be overcome by using data collection methods such as observation and interview. The impact of school quality, one of the school-related factors, on school burnout was investigated in this study. It is suggested that the factors arising from the individual or social environment that have an impact on school burnout should be included as a variable in the future studies. In this context, researchers who will carry out new studies on this subject could include another variable that affects the quality of school life and could examine the mediating role of school life quality between that variable and school burnout.

\section{CONCLUSION}

High perception of school life quality of students plays an important role in overcoming the negative effects of school burnout, which is seen as a common problem for students. It can be suggested that the studies to increase the perceptions of school's life quality will decrease the effects of negative situations such as students' exhaustion from the lessons, their feeling of boredom towards the school, and the decreased desire to participate in the lessons. According to the results obtained in the study, it can be suggested to the teachers, school psychological counselors and school administrators that there will be positive implications of planning activities and involving different activities in programs in order to improve the quality of school life for students to show a better attitude towards the school.

\section{REFERENCES}

[1] Salmela-Aro, K., Kiuru, N., Leskinen, E., and Nurmi, J., "School burnout inventory (SBI): reliability and validity," European Journal of Psychological Assessment, vol. 25, no. 1, pp. 48-57, 2009.

[2] Gan, Y. and Shang, J., "Coping flexibility and locus of control as predictors of burnout among Chinese college students," Social Behavior and Personality, vol. 35, no. 8, pp. 1087-1098, 2007.

[3] Parker, P. D. and Salmela-Aro, K., "Developmental processes in school burnout: A comparision of major developmental models," Learning and Individual Differences, vol. 21, no. 2, pp. 244-248, 2011.

[4] Walburg, V., "Burnout among high school students: A literature review," Children and Youth Services Review, vol. 42, pp. 28-32, Jul 2014.

[5] Seçer, İ., "Üniversite öğrencilerinde okul tükenmişliği ile psikolojik uyumsuzluk arasındaki ilişkinin incelenmesi," Atatürk Üniversitesi Sosyal Bilimler Enstitüsü Dergisi, vol. 19, no. 1, pp. 81-99, 2015.

[6] Schaufeli, W. B. et al., "Burnout and engagement in university students: A cross-national study," Journal of Crosscultural Psychology, vol. 33, no. 5, pp. 464-481, 2002.

[7] Çapri, B., Gündüz, B., and Gökçakan, Z., "Maslach tükenmişlik envanteriöğrenci formu'nun (mte-öf) Türkçe’ye uyarlaması geçerlik ve güvenirlik çalışması,” Çukurova Üniversitesi Eğitim Fakültesi Dergisi, vol. 40, no. 1, pp. 134-147, 2011.

[8] Aypay, A., "İlköğretim II. kademe öğrencileri için okul tükenmişliği ölçeği: Geçerlik ve güvenirlik çalışması," Kuram ve Uygulamada Eğitim Bilimleri, vol. 11, no. 2, pp. 511-527, 2011.

[9] Gündoğan, S., "Lise öğrencilerinin okul tükenmişliklerinin sosyal destek ve çeşitli değişkenler açısından incelenmesi," OPUS- Uluslararası Toplum Araştırmaları Dergisi, vol. 13, no. 19, pp. 25-49, 2019.

[10] Lehto, J. E., Kortesoja, L., and Partonen, T., "School burnout and sleep in finnish secondary school students," Sleep Science, vol. 12, no. 1, pp. 10-18, 2019.

[11] Love, H., May, R. W., Cui, M., and Fincham, F. D., "Helicopter parenting, self-control, and school burnout among emerging adults," Journal of Child and Family Studies, vol. 29, no. 2, pp. 327-337, 2020.

[12] Fiorilli, C., et al., "School burnout, depressive symptoms and engagement: Their combined effect on student achievement," International Journal of Educational Research, vol. 84, pp. 1-12, 2017.

[13] Salmela-Aro, K., et al., "School burnout and engagement profiles among digital natives in Finland: A personoriented approach,” European Journal of Developmental Psychology, vol. 13, no. 6, pp. 704-718, 2016.

[14] Paloș, R., Maricuţoiu, L. P., and Costea, I., "Relations between academic performance, student engagement and student burnout: A cross-lagged analysis of a two-wave study," Studies in Educational Evaluation, vol. 60, pp. 199-204, Mar 2019.

[15] Salmela-Aro, K. and Tynkkynen, L., "Gendered pathways in school burnout among adolescents," Journal of Adolescence, vol. 35, no. 4, pp. 929-939, 2012.

[16] Aunola, K., et al., "The role of parental affection and psychological control in adolescent athletes' symptoms of school and sport burnout during the transition to upper secondary school," Journal of Adolescence, vol. 69, pp. 140-149, Dec 2018.

Int. J. Eval. \& Res. Educ. Vol. 9, No. 3, September 2020: 531 - 538 
[17] Salanova, M., Schaufeli, W. B., Martínez, I., and Bresó, E., "How obstacles and facilitators predict academic performance: The mediating role of study burnout and engagement," Anxiety, Stress, and Coping, vol. 23, no. 1, pp. 53-70, 2010.

[18] May, R. W., Bauer, K. N., and Fincham, F. D., "School burnout: Diminished academic and cognitive performance," Learning and Individual Differences, vol. 42, pp. 126-131, Aug 2015.

[19] Meier, S. T. and Schmeck, R. R., "The burned-out college student: A descriptive profile," Journal of College Student Personne, vol. 26, no. 1, pp. 63-69, 1985.

[20] Aypay, A., "Ortaöğretim öğrencileri için okul tükenmişliği ölçeği OOTÖ,” Kuram ve Uygulamada Eğitim Bilimleri, vol. 12, no. 2, pp. 773-787. 2012.

[21] Dahlin M.E. and Runeson B., "Burnout and psychiatric morbidity among medical students entering clinical training: a three year prospective questionnaire and interview-based study," BMC Medical Education, vol. 7, no. 1, pp. 6-14, 2007.

[22] Salmela-Aro, K., Savolainen, H., and Holopainen, L., "Depressive symptoms and school burnout during adolescence: Evidence from two cross-lagged longitudinal studies," Journal of Youth and Adolescence, vol. 38, no. 10 , pp. 1316-1327, 2009.

[23] Koçak, L. and Seçer, İ., "Lise öğrencilerinde okul tükenmişliği ile depresyon ve kaygı arasındaki ilişkinin incelenmesi," Çukurova Üniversitesi Ĕgitim Fakültesi Dergisi, vol. 47, no. 2, pp. 601-622, 2018.

[24] Seibert, G. S., May, R. W., Fitzgerald, M. C., and Fincham, F. D., "Understanding school burnout: Does selfcontrol matter?" Learning and Individual Differences, vol. 49, pp. 120-127, Jul 2016.

[25] May, R. W., Seibert, G. S., Sanchez-Gonzalez, M. A., and Fincham, F. D., "Self-regulatory biofeedback training: an intervention to reduce school burnout and improve cardiac functioning in college students," Stress, vol. 22, no. 1, pp. 1-8, 2019.

[26] Salmela-Aro, K., Tynkkynen, L., and Vuori, J., "Parents' work burnout and adolescents' school burnout: Are they shared?" European Journal of Developmental Psychology, vol. 8, no. 2, pp. 215-227, 2011.

[27] Çam, Z., Deniz, K. Z, and Kurnaz, A., "Okul tükenmişliği: algılanan sosyal destek, mükemmeliyetçilik ve stres değişkenlerine dayalı bir yapısal eşitlik modeli sınaması,” Eğitim ve Bilim, vol. 39, no. 173, pp. 312-327, 2014.

[28] Salmela-Aro, K., and Upadyaya, K., "School burnout and engagement in the context of demands-resources model," British Journal of Educational Psychology, vol. 84, no. 1, pp. 137-151, 2014.

[29] Özdemir, Y., "Ortaokul öğrencilerinde okul tükenmişliği: Ödev, okula bağll1ık ve akademik motivasyonun rolü," Adnan Menderes Üniversitesi Eğitim Fakültesi Ĕ̈itim Bilimleri Dergisi, vol. 6, no. 1, pp. 27-35, 2015.

[30] Şahan, B. and Duy, B., "Okul tükenmişliği: okula bağlanma, sosyal destek ve öz yeterliliğin yordayıcı rolü," Mersin Üniversitesi Ë̆itim Fakültesi Dergisi, vol. 13, no. 3, 1249-1270, 2017.

[31] Altuntaş, S. and Sezer, Ö., "Investigating school attachment of secondary school students," Inonu University Journal of the Faculty of Education, vol. 18, no. 1, pp. 83-97, 2017.

[32] Malinen, O. P. and Savolainen, H., "The effect of perceived school climate and teacher efficacy in behavior management on job satisfaction and burnout: A longitudinal study," Teaching and Teacher Education, vol. 60, pp. 144-152, Nov 2016

[33] Durmuş, E., Aypay, A., and Aybek, E. C., "Okul tükenmişliğini önlemede ebeveyn izlemesi ve olumlu okul iklimi," Kuram ve Uygulamada Eğitim Yönetimi Dergisi, vol. 23, no. 3, pp. 355-386, 2017.

[34] Sarı, M., "Okul yaşamının değerlendirilmesi: Okul yaşam kalitesi ölçeği'nin güvenirlik ve geçerliği," Hacettepe Üniversitesi Ĕgitim Fakültesi Dergisi, vol. 42, no. 42, pp. 344-355, 2012.

[35] Thien, L. M., "Assessing a second-order quality of school life construct using partial least squares structural equation modelling approach," International Journal of Research and Method in Education, vol. 43, no. 3, pp. 1$14,2019$.

[36] Epstein, J. L. and McPartland, J. M., "Classroom organization and the quality of school life," Maryland: Center for Social Organization of Schools, 1976.

[37] Epstein, J. L. and McPartland, J. M., "The concept and measurement of the quality of school life," American Educational Research Journal, vol. 13, no. 1, pp. 15-30, 1976.

[38] Karatzias, A., Power, K. G., and Swanson, V., "Quality of school life: Development and preliminary standardisation of an instrument based on performance indicators in Scottish secondary schools," School Effectiveness and School Improvement, vol. 12, no. 3, pp. 265-284, 2001.

[39] Thien, L. M. and Razak, N. A., "Academic coping, friendship quality, and student engagement associated with student quality of school life: A partial least square analysis," Social Indicators Research, vol. 112, no. 3, pp. 679-708, 2013.

[40] Sarı, M., "Okul yaşam kalitesi: Tanımı, değişkenleri ve ölçülmesi," Çukurova Üniversitesi Eğitim Fakültesi Dergisi, vol. 3, no. 32, pp. 139-151, 2006.

[41] Wright, M. and Scullion, P., "Quality of school life and attitudes to Irish in the Irish-medium and English-medium primary school," Irish Educational Studies, vol. 26, no. 1, pp. 57-77, 2007.

[42] Thien, L. M., Karpudewan, M., and Chin, H., "Conceptualising Malaysian Chinese primary school students' quality of school life: a mixed methods study," Educational Studies, pp. 1-19, 2019. [Online]. Available: https://doi.org/10.1080/03055698.2019.1651693

[43] Kaya, A., and Sezgin, M., "Ortaokul öğrencilerinin mutluluklarının eğitim stresi ve okul yaşam kalitesi tarafından yordanması," Mehmet Akif Ersoy Üniversitesi Eğitim Fakültesi Dergisi, vol. 1, no. 41, pp. 245-264, 2017.

[44] Kong, C. K., "Classroom learning experiences and students' perceptions of quality of school life," Learning Environments Research, vol. 11, no. 2, pp. 111-129, 2008. 
[45] Leonard, C., Bourke, S., and Schofield, N., "Quality of school life and absenteeism in primary schools," Paper presented at the AARE Annual Conference, The University of New Castle, 2000.

[46] Ayık, A. and Ataş-Akdemir, Ö., "Öğretmen adaylarının okul yaşam kalitesi ve okula yabancılaşma algıları arasındaki ilişki," Kuram ve Uygulamada Eğitim Yönetimi, vol. 21, no. 4, pp. 429- 452, 2015.

[47] Büyüköztürk, Ș., et al., Bilimsel araștırma yöntemleri. Ankara: PegemA Yayınları, 2014.

[48] Bayram, N., Yapısal eşitlik modellemesine giriş. Ankara: Ezgi Kitabevi, 2011.

[49] Seçer, İ., Halmatov, S., Veyis, F., and Ateş, B., "Okul tükenmişlik ölçeğinin Türk kültürüne uyarlanması: Güvenirlik ve geçerlik çalışması,” Turkish Journal of Education, vol. 2, no. 2, pp. 16-24, 2013.

[50] Hair, J. F., Black, W. C., Babin, B. J., and Anderson, R. E., Multivariate data analysis: Pearson new international edition. Pearson Higher Ed, 2013.

[51] Seçer, İ., SPSS ve LISREL ile pratik veri analizi. Ankara: Anı Yayınc1lık, 2013.

[52] Büyüköztürk, Ş., Sosyal bilimler için veri analizi el kitabı. Ankara: Pegem A Yayıncılık, 2007.

[53] Byrne, B. M., Structural equation modeling with Mplus: Basic concepts, applications, and programming. Routledge, 2013.

[54] Bentler, P.M. and Bonett, D.G., "Significance tests and goodness-of-fit in the analysis of covariance structures," Psychological Bulletin, vol. 88, no. 3, pp. 588-606, 1980.

[55] Bollen, K.A., Structural Equations with Latent Variables. New York: Wiley, 1989.

[56] Marsh, H.W., Balla, J.R., and McDonald, R.P., "Goodness-of-fit indexes in confirmatory factor analysis: the effect of sample size," Psychological Bulletin, vol. 103, no. 3, pp. 391-410, 1988.

[57] Şimşek, Ö. F., Yapısal eşitlik modellemesine giriş; Temel ilkeler ve LiSREL uygulamaları. Ankara: Ekinoks Yayıncilik, 2007.

[58] Seçer, İ., and Gençdoğan, B., "Ortaöğretim öğrencilerinde okul tükenmişliğinin çeşitli değişkenlere göre incelenmesi," Turkish Journal of Education, vol. 1, no. 2, pp. 25-37, 2012.

[59] Zanganeh, N., and Aghaei, A., "Correlation between Organizational Culture, Quality of Work Life and Burnout (Case study: Golestan Province State Hospitals)," International Research Journal of Management Science, vol. 1, no. 2, pp. 27-32, 2013.

[60] Jaafarpour, M., and Mahamodian, M. R., "Evaluation of the quality of nursing work life and its association with job burnout in Isfahan University of Medical Sciences," International Journal of Epidemiologic Research, vol. 2, no. 1, pp. 30-39, 2015.

[61] Acar, A. and Erkan, M., "The effects of quality of work life on burnout syndrome: A study on hospitality industry," Journal of Tourismology, vol. 4, no. 1, pp. 35-53, 2018.

[62] Akar, H., "The relationships between quality of work life, school alienation, burnout, affective commitment and organizational citizenship: A study on teachers," European Journal of Educational Research, vol. 7, no. 2, pp. 169-180, 2018. 